Environment Conservation Journal 15(3)95-99, 2014

ISSN 0972-3099 (Print) 2278-5124 (Online)

Abstracted and Indexed

\title{
Prospects of mushroom cultivation in Punjab
}

\author{
Ramanpreet Singh and Prabhjot Kaur $\bowtie$
}

Received:16.12.2013
Revised: 06.05.2014
Accepted:14.08.2014

\begin{abstract}
Productivity of rice and wheat, the major crops of the state, is reported to have approached a plateau and farm income is reported to be stagnant. There is need to promote different auxiliary enterprises among farmers. Keeping all these things in view study on prospects of mushroom cultivation in Punjab was conducted. From six clusters, two clusters were selected randomly. From these two clusters 90 farmers were selected randomly for the purpose of this study. An interview schedule was prepared for collection of data. Data were collected personally by the researcher. Majority had adopted mushroom cultivation as main occupation $(63 \%)$, obtained information from friends. Regarding experience in mushroom cultivation majority of the farmers $(43.33 \%)$ had experience of 7-14 years. More than 25 per cent of the respondents were willing to decrease their area under mushroom cultivation and only 3.33 per cent of the respondents had plan to keep area constant under mushroom cultivation
\end{abstract}

Keywords: mushroom, production, Prospects, straw, trend

\section{Introduction}

The green revolution tremendously increased food production, accelerated the pace of modernization and urbanization in the state by strengthening economic base of the rural people. On the other side, green revolution created serious regional imbalances in the production of cereals. There is growing pressure of population on land as the size of the operational land holding is declining. Continued degradation and mis-management of land, soil, water, high cost of production and diminishing economic returns in farming are adversely affecting the farmers in Punjab. Productivity of rice and wheat, the major crops of the state, is reported to have approached a plateau and farm income is reported to be stagnant. Mushroom farming is economically a very much viable enterprise. It can be adopted by small, medium and large investors by investing according to the capacity. Other than high profit, it is a fast earning activity and start giving returns within weeks and months. Besides utilizing agro(industrial wastes, it does not require arable land and waste-lands may be put into use for mushroom Author's Address

${ }^{1}$ Department of Extension Education

Punjab Agricultural University (Ludhiana)

E-mail:prabhjot1962@pau.edu farming as such, marginal or even land-less laborers may also take up mushroom farming at a small scale to earn their livelihood and some nutritious food for their families. Mushroom farming is labor-intensive and generates employment. Several activities of this enterprise like spawn-production, processing and marketing can be carried out by women-folk and the farmers may involve their family members to augment income. Thus mushroom farming is highly profitable, sustainable economic activity capable of exerting positive impact on the rural scenario of our country. Mushroom has a huge potential for export due to expanding global market. Punjab occupies just 1.53 per cent of the geographical area of India, yet it produces as much as 31014 tons of mushrooms annually accounting for more than 50 per cent of the national production (Anonymous, 2014). Keeping all these things in view study on prospects of mushroom cultivation in Punjab was conducted.

\section{Material and Methods}

List of trainees who got training in mushroom cultivation during last five years was obtained from the office of Directorate of Extension Education, PAU Ludhiana. From this list, six clusters were 
prepared based on the concentration of mushroom trained farmers and from these six clusters, two clusters were selected randomly. From these two clusters, 90 farmers were selected randomly for the purpose of this study.

\section{Data Collection}

The data were collected personally by the researcher by visiting the study area and personally interviewing the respondents.

Statistical tools used: The data were analyzed with the help of various statistical tools such as frequencies, percentagesand cumulative frequency cube root method.

\section{Results and Discussion}

The results of the study have been discussed under the following headings.

\section{Education}

The data given in Table 1 showed that more than 35 per cent of the respondents had education up to matric, 27.78 per cent up to middle, while 13.34 per cent of them were graduates. It was further found that 12.23 per cent were educated up to primary level and 10.00 per cent of the respondents were illiterate. Overall education level of the respondents was below matric. These findings are in line with those of Kher (1991), Kadam Borse (1993) and Sharma (1996).

\section{Operational Land holding}

Operational land holding of the respondents was categorized into three categories. The study findings revealed that respondents' operational land holding ranged from 1 to 10 acres. As many as 64.44 per cent of the respondents were operating on 5-10 acres of land, 24.45 per cent of them were operating on 1-5 acres of land, whereas 11.11 per cent of the respondents were operating on above 10 acres of land. Similar findings have been reported by Lanjewuar and Rathore (2007).

\section{Family type}

Data presented in Table 1 further indicate that majority $(67.78 \%)$ of the respondent's belonged to nuclear families while 32.22 per cent of the respondents belonged to joint families. Similar findings have been reported by Singh (1989) and Suraj (1996).

\section{Family Size}

The figures presented in Table 1 showed that more than 52 per cent of the respondents had family size up to five members while 47.78 per cent of the member had above five members of family.

\section{Occupation}

Data in Table 1 further revealed that more than 63 per cent of the respondents adopted mushroom cultivation as a main occupation whereas 36.67 per cent of the respondents adopted mushroom cultivation as a subsidiary occupation.

\section{Sources of information}

The information pertaining to farmers' source of information regarding mushroom cultivation has been given in Table 1 . The figures in Table 1 revealed that 47.78 per cent of the respondents had come to know about mushroom cultivation from friends, followed by PAU scientists $(33.33 \%)$ and relatives $(15.55 \%)$. However, for 3.33 per cent of the respondents, newspaper was the first source of information regarding mushroom cultivation. These results are similar to the findings of Singh and Parshad (1990).

\section{Total production in a year}

The total production of mushroom cultivation was categorized into three categories viz. Low, medium and high. Majority (46.67\%) of the respondents had medium level of production i.e. 100-350 qts/acre whereas 41.11 per cent of the member had low (up to 100 qts/acre) level production of mushroom while 12.22 per cent of the respondents had high level of mushroom production (above 350 qts/acre).

\section{Annual income of mushroom growers}

The annual income of mushroom growers was categorized into low, medium and high. Majority $(62.22 \%)$ of the respondents had high annual income (Rs 4,00,000- 6,00,000) followed by 26.67 per cent of the respondents who had medium annual income (Rs 2,00,000-4,00,000) and 11.11 per cent of them had low annual income which ranged up to (Rs 2,00,000). 
Table 1: Profile of the respondents engaged in mushroom cultivation

\begin{tabular}{|c|c|c|c|c|}
\hline $\begin{array}{l}\text { Sr. } \\
\text { no. }\end{array}$ & Socio-personal Characteristics & Category & Frequency & Percentage \\
\hline \multirow{5}{*}{1} & \multirow{5}{*}{ Education } & Illiterate & 9 & 10.00 \\
\hline & & Primary & 11 & 12.23 \\
\hline & & Middle & 25 & 27.78 \\
\hline & & Matric & 33 & 36.67 \\
\hline & & Graduate & 12 & 13.34 \\
\hline \multirow{3}{*}{2} & \multirow{3}{*}{$\begin{array}{l}\text { Operational land } \\
\text { Holding(acres) }\end{array}$} & $1-5$ & 22 & 24.45 \\
\hline & & $5-10$ & 58 & 64.44 \\
\hline & & Above 10 & 10 & 11.11 \\
\hline \multirow{2}{*}{4} & \multirow{2}{*}{ Family type } & Nuclear & 61 & 67.78 \\
\hline & & Joint & 29 & 32.22 \\
\hline \multirow{2}{*}{5} & \multirow{2}{*}{ Family size } & up to 5 & 47 & 52.22 \\
\hline & & above 5 & 43 & 47.78 \\
\hline \multirow{2}{*}{6} & \multirow{2}{*}{ Occupation } & main occupation & 57 & 63.33 \\
\hline & & subsidiary occupation & 33 & 36.67 \\
\hline \multirow{4}{*}{7} & \multirow{4}{*}{ Sources of information } & Friends & 43 & 47.78 \\
\hline & & Relatives & 14 & 15.55 \\
\hline & & PAU Scientists & 30 & 33.33 \\
\hline & & newspapers & 3 & 3.33 \\
\hline \multirow[t]{4}{*}{9} & Total production in a year (qts) & & & \\
\hline & Up to 100 & Low & 37 & 41.11 \\
\hline & $100-350$ & Medium & 42 & 46.67 \\
\hline & Above 350 & High & 11 & 12.22 \\
\hline \multirow[t]{4}{*}{10} & Annual income ofmushroom growers (Rs) & & & \\
\hline & Upto $2,00,000$ & Low & 10 & 11.11 \\
\hline & $2,00,000-4,00,000$ & Medium & 24 & 26.67 \\
\hline & $4,00,000-6,00,000$ & High & 56 & 62.22 \\
\hline
\end{tabular}

\section{Experience in mushroom cultivation}

The experience of the respondents in mushroom cultivation ranged up to 21 years. A perusal of data set in Table 2 reveals that about 44 per cent of respondents had experience of 7-14 years in mushroom cultivation, whereas 34.45 per cent of the respondents had 14-21 years and 22.22 per cent of them had up to seven years of experience in mushroom cultivation.

\section{Area under mushroom cultivation}

The area cultivated by the respondents under mushroom ranged from less than 50 sq. meter to more than 100 sq. meter. This range was categorized into three categories i.e. less than 50, $50-100$ and more than 100 square meters. It is interesting to note from the Table 2 that little more than half of the respondents (55.56 per cent) cultivated more than 100 sq. mts area under mushroom and 31.11 per cent of the respondents cultivated $50-100$ sq. mts where as 13.33 per cent of them had less than 50 sq. mts area under mushrooms cultivation.

\section{Trend of mushroom cultivation}

A perusal of the data given in Table 3 reveals that 71.11 per cent of the respondents wanted to increase area under mushroom cultivation. About 35 per cent of the respondents wanted to increase their area under mushroom cultivation as they fetched good income, 21.11 per cent reported that it can be grown on unfertile land and 15.56 per cent of the respondents wanted to increase area/unit size 
under mushroom cultivation as they can be grown indoor without occupying much space. It is evident from the Table 3 that only 25.56 per cent of the respondents planned to decrease the area under mushroom cultivation.
A critical look at the data revealed that about 11.00 per cent of the respondents planned to decrease area/unit size under mushroom cultivation due to non-availability of subsidy, 7.78 per cent of them want to decrease area due to lack of skilled labor,

Table 2: Distribution of the respondents on the basis of experience and area under mushroom cultivation

\begin{tabular}{|l|l|l|l|}
\hline Category & Range & Frequency & Percentage \\
\hline \multirow{3}{*}{ Experience in mushroom cultivation (years) } & upto-7 & 20 & 22.22 \\
\cline { 2 - 4 } & $7-14$ & 39 & 43.33 \\
\cline { 2 - 4 } & $14-21$ & 31 & 34.45 \\
\hline \multirow{2}{*}{ Area under mushroom cultivation (sq.mts) } & Less than 50 & 12 & 13.33 \\
\cline { 2 - 4 } & $50-100$ & 28 & 31.11 \\
\cline { 2 - 4 } & More than 100 & 50 & 55.56 \\
\hline
\end{tabular}

Table 3: Distribution of the respondents on the basis of Trend of mushroom cultivation

\begin{tabular}{|c|c|c|c|c|c|c|}
\hline Trend & Response & Frequency & Percentage & Reasons & Frequency & Percentage \\
\hline \multirow{4}{*}{$\begin{array}{l}\text { Continue } \\
\text { mushroom } \\
\text { cultivation }\end{array}$} & Yes & 69 & 76.66 & Profitable & 69 & 76.66 \\
\hline & \multirow{3}{*}{ No } & \multirow{3}{*}{21} & \multirow{3}{*}{23.33} & $\begin{array}{l}\text { Spoilage of } \\
\text { compost }\end{array}$ & 4 & 4.44 \\
\hline & & & & $\begin{array}{l}\text { Non-availability } \\
\text { of skilled labor }\end{array}$ & 11 & 12.22 \\
\hline & & & & $\begin{array}{l}\text { Lengthy } \\
\text { procedure of } \\
\text { cultivation }\end{array}$ & 6 & 6.70 \\
\hline \multirow{3}{*}{ Increase } & \multirow{3}{*}{ Yes } & \multirow{3}{*}{64} & \multirow{3}{*}{71.11} & Good income & 31 & 34.44 \\
\hline & & & & Indoor grown & 14 & 15.56 \\
\hline & & & & $\begin{array}{l}\text { Can be grown on } \\
\text { unfertile land }\end{array}$ & 19 & 21.11 \\
\hline \multirow[t]{3}{*}{ Decrease } & \multirow{3}{*}{ Yes } & \multirow{3}{*}{23} & \multirow{3}{*}{25.56} & $\begin{array}{l}\text { Lack of Skilled } \\
\text { labor }\end{array}$ & 7 & 7.78 \\
\hline & & & & Spoiled compost & 6 & 6.67 \\
\hline & & & & No subsidy & 10 & 11.11 \\
\hline Constant & Yes & 3 & 3.33 & $\begin{array}{l}\text { Higher cost of } \\
\text { straw }\end{array}$ & 3 & 3.33 \\
\hline
\end{tabular}

whereas, only 6.67 per cent wanted to decrease area due to spoilage of compost. It can be observed from the data in Table 3 that 3.33 per cent of the respondents neither willing to increase nor decrease area under mushroom cultivation due to higher cost of straw.

\section{Conclusion}

It can be concluded that majority of the mushroom growers had their friends as their first source of information about mushroom cultivation (47.78\%), total production $100-350$ qts/acre in a year (46.67\%) and their annual income of Rs up to above 6,00,000/acre (62.22\%). Regarding experience in mushroom cultivation majority of the farmers (43.33\%) had experience of 7-14 years. More than 25 per cent of the respondents were willing to decrease their area under mushroom cultivation and only 3.33 per cent of the respondents had plan to keep area constant under mushroom cultivation. 


\section{References}

Anonymous, 2014. Statement Showing the Districtwise Production of Mushroom in the State of Punjab for the year 2011-12. Retrieved from http://punjabhorticulture.com/wpcontent/themes/twentyeleven/document/Mushroom/Mushr oom_2011-12.pdf on 19/5/2014.

Kadam, K. R. and Borse, A. V., 1993. Adoption behavior of banana growers. Maha J Ext Edu 12: 45-56.

Kher, S. K., 1991. Adoption behavior of rainfed maize growers. Maha J Ext Edu 10: 271-73.

Lanjewar, D. M. and Rathore, M. K., 2007. Utility perception about ICT among farmers. Asian J of Ext Edu 27: $95-101$.
Sharma, D., 1996. Adoption of selected recommended practices of mango growers in Punjab. Ph. D. Thesis submitted to Punjab Agricultural University, Ludhiana India.

Singh, B. B. and Parshad, R. B., 1990 Farmers choice of information sources and knowledge of technology of afforestation of salt affected soils. Ind J Ext Edu26: 92-94.

Singh, M., 1989. Structure and functioning of Punjab Kisan club- A case study. M.Sc Thesis submitted to Punjab Agricultural University, Ludhiana India

Suraj, J. S., 1996. Adoption gap between recommended practices and practices followed by the pear growers of Jalandhar district, Punjab. M. Sc Thesis submitted to Punjab Agricultural University, Ludhiana India 